\title{
ŠPANĚLSKÝ KARDINÁL ZEFERINO GONZÁLES Y DÍAZ TUÑON OP (1831-1894) A EVOLUČNÍ VZNIK ČLOVĚKA
}

\author{
C T I R A D V. P O S P Í Š I L
}

\section{ABSTRACT \\ Spanish Cardinal Zeferino Gonzáles y Díaz Tuñon OP (1821-1894) and Evolutionary Origin of Man}

This study presents the life and works of the Spanish Catholic philosopher and cardinal Zeferino Gonzalez (183-1894), who is very little known in the Czech environment. The focus of this study is an analysis of the La Biblia y la Ciencia published in 1891, in which the author - as a high church official - expressed his support for the acceptability of Mivart's thesis. Which one he modified by claiming that the body of an animal prepared by evolution became fully human in the moment of unification with a rational soul. In this work, the Spanish Cardinal responded to Draper's book on the Discrepancy Between Science and Religion. His approach to contemporary natural science, paleontology and paleoanthropology was quite honest critical. Once these sciences provided conclusive results that contradicted to the traditional exegesis of the biblical text, in particular on the basis of the texts of St. Augustine and St. Thomas Aquinas, cardinal has been able to modify the interpretation of these texts in such a way that there is no contradiction between the faith and the results of human reason. Finally, it must be underlined that González's work has allowed us to identify three other French pioneers of accepting evolutionary origin - creation of man by Christian thinking.

\section{Keywords}

Evolution; Origin of a man; Darwinism; Theology of creation; History of theology; Exegesis; Old Testament; Book of Genesis

DOI: $10.14712 / 23363398.2018 .17$

\section{$\mathrm{P}$}

ředkládaná studie je součástí rozsáhlého souboru pilotních příspěvků, jehož cílem je objasnit průběh první fáze recepce hypotézy evolučního vzniku - stvoření člověka v období let 1871-1910 (1920) ze 
strany katolické teologie na široké mezinárodní rovině. Právě zmíněný badatelský záměr je pokračováním předchozího mnohaletého výzkumu v oblasti reakcí českých katolických teologů na výzvy přírodních věd zejména v období let 1850-1950. ${ }^{1}$ Po anglosaských, německých a rakouských, italských, francouzských a belgických průkopnících ${ }^{2}$ zaměříme nyní pohled za Pyreneje do katolického, a jak uvidíme zakrátko, nevyhnutelně také antikatolického Španělska, kde působili dva vynikající teologové z Řádu bratří kazatelů, kteří v devadesátých letech předminulého století otvírali možnosti sladění přínosů moderní přírodovědy, specificky hypotézy evolučního vzniku člověka a objevů dobové paleoantropologie s křestanskou vírou. Jedná se v první řadě o Zeferina Gonzálese $\mathrm{OP}$, o němž a jehož díle pojednáme v tomto příspěvku. V následujícím se zaměříme na Juana Gonzálese de Arintero OP (1860-1928).

Studie bude rozvržena do tří nestejnoměrných částí. V první se velmi stručně zmíníme o problematice španělského darwinismu a antidarwinismu v posledních třech desetiletích 19. století, protože zmíněné téma není u nás téměř vůbec známo. Ve druhé seznámíme české čtenáře s hlavními událostmi a charakteristikami životního příběhu Z. Gonzálese.

Mělo by být srozumitelné, že tyto první dvě části mají pouze přípravný charakter, protože náš vlastní př́nos se bude nacházet výhradně ve třetí pasáži, v níž představíme stěžejní dílo zmíněného autora, zaměřené na problematiku evoluce, a poněkud detailněji zanalyzujeme jeho vybrané partie. Již na tomto místě se zdá být vhodné podtrhnout, že v české odborné literatuře bychom jen obtížně nalezli nejenom původní, ale i překladovou studii věnovanou tomuto významnému španělskému teologovi.

1 Srov. C. V. Pospíšil. Zápolení o pravdu, naději a lidskou důstojnost: Česká katolická teologie 1850-1950 a výzvy přirodnich véd v širšim svétovém kontextu. Praha: Karolinum 2017.

2 V době vzniku této studie dotyčné příspěvky ještě nevyšly na stránkách Studia theologica ani v periodiku Acta Universitatis Carolinae - Theologica, a proto na ně zatím nemůžeme odkazovat. 


\section{Základní informace o španělském darwinismu a antidarwinismu $v$ letech 1850-1910}

Určitou předehru sporů o evoluční problematiku ve Španělsku představují tři katalánští přírodovědci, kteří nedlouho po roce 1800 naslouchali v Pařiži Lamarckovým přednáškám. Byli to konkrétně: fyzik Josep Garriga; geolog Carles Gimbernat; třetím byl student z Barcelony, jehož jméno se nezachovalo. Důležitou roli v tomto prvním období otevírání se evolucionistické koncepci vzniku druhů sehrál chemik a prrírodovědec Antonio Martí Franquès, jehož žák Augustí Yaňez i Girona, profesor př́rodní historie na univerzitě v Barceloně, publikoval v roce 1842 lamarckisticky laděný slovník s nadpisem Dios y sus obras: Diccionario pintoresco de historia natural y de agricultura. ${ }^{3}$ V roce 1860 se v Revista de los Progressos de las Ciencias, kterou vydávala Akademie exaktních věd v Madridu, objevil překladový článek Charlese Leylla, v němž se tento světoznámý geolog vyslovoval k Darwinově dílu o vzniku druhů. ${ }^{4}$

Postoj k darwinismu ve Španělsku výrazně souvisel s vyhrocenou vnitropolitickou situací, která vyvrcholila v září 1868 revolucí a dočasným ochromením staleté monarchie. Nová státoprávní situace podle mínění znalců výrazně otevřela dveře pozitivnímu přijetí evolucionismu, proti čemuž se vcelku pochopitelně stavěly konzervativní a monarchisticky orientované kruhy. ${ }^{5}$ Po restauraci královské moci v roce 1875 byla španělská odborná veřejnost samozřejmě značně polarizovaná.

Další, pro nejednoho českého odborníka velmi překvapivá informace se týká dlouhé tradice i nezanedbatelné kvality španělských studií v oblasti paleontologie, což vycházelo přednostně z bohatých nálezů fosilií v amerických koloniích z 16. a 17. století. První univerzitní profesor paleontologie ve Španělsku Juan Vilanova y Piera (1821-1893) a jeho žák i nástupce Francisco Vidal y Careta (1860-1923)

3 Srov. Augustí Camós. Darwin in Catalunya: From Catholic Intransigence to the Marketing of Darwin's Image. In: Eve-Marie Engels - Thomas F. Glick (eds.). The Reception of Charles Darwin in Europe 1-2. London - New York: Continuum 2008, s. 400-412, zde 401.

4 Srov. Francisco Pelayo. Darwinism and Paleontology: Reception and Diffusion of the Theory of Evolution in Spain. In: Eve-Marie Engels - Thomas F. Glick (eds.). The Reception of Charles Darwin in Europe 1-2, s. 386-399, zde 386.

5 Srov. Thomas F. Glick. Darwin en Espaňa. Valéncia: Universitat de Valéncia 2010, s. 13-15. 
se k darwinistickým hypotézám vyslovovali velmi kriticky, přičemž se odvolávali na práce Joachima Barrandeho. ${ }^{6}$

Dále je třeba připomenout, že v roce 1872 profesor Augusto Gonzáles de Linares poprvé ve svých přednáškách předložil pozitivní hodnocení Darwinových idejí, což vyvolalo ostré rozdělení mezi jeho posluchači. ${ }^{7}$ Rozhodně není bez zajímavosti, že rok po obnovení monarchie vyšla v překladu do kastilštiny Darwinova kniha o původu člověka El origen del hombre (1876), až o rok později spatřila světlo světa španělská verze starší monografie téhož autora o vzniku druhů El origen de las species (1877). Ve Španělsku se však podle odborníkủ diskutovalo o darwinismu již od roku 1868, a to na základě francouzského překladu Darwinova díla o původu druhů. ${ }^{8}$ Byly to roky ostrých kontroverzí, jak jsme již naznačili výše.

K šíření evolucionistické koncepce biologie a zoologie přispěly španělské překlady spisu Ernesta Haeckela. Předním propagátorem idejí německého přírodovědce byl ve Španělsku valencijský anatom Peregrín Casanova Ciurano (1849-1919)..$^{9}$ Není divu, že katolická opozice odsoudila Haeckelovy ideje jako materialistické a ateistické, ${ }^{10}$ což o jejich světonázorovém přesahu určitě platí. Jako příklad takovéto ostře odmítavé pozice vủči darwinistickému evolucionismu můžeme uvést studii katolického novelisty Emilia Pardo Bazána Reflexiones cientificas sobre el darwinismo, ${ }^{11}$ uveřejněnou v Ciencia Cristiana. Pro nás je podstatné, že právě zmíněné periodikum založil autor, jímž se nyní míníme zabývat podrobněji, tedy Zeferino Gonzáles.

V průběhu našich studií jsme již vícekrát narazili na bouřlivou debatu o existenci člověka ve třetihorách, která se odehrávala v osmdesátých letech předminulého století v západní Evropě. Stejně jako jinde na starém kontinentu docházelo i ve Španělsku ke střetu pozitivního a negativního hodnocení uvedeného předpokladu. ${ }^{12}$ Obecněji řečeno,

6 Srov. Francisco Pelayo. Darwinism and Paleontology: Reception and Diffusion of the Theory of Evolution in Spain, s. 390.

7 Srov. Thomas F. Glick. Darwin en Espaňa, s. 16.

8 Srov. tamtéž, s. 17.

9 Srov. např. Peregrín Casanova Ciurano. La biología general. Estudios biológicos I. Valencia: Ferrer de Orga 1877.

10 Srov. Thomas F. Glick, Darwin en Espaňa, s. 19-20.

11 Emilio Pardo Bazán. Reflexiones cientificas sobre el darwinismo. Ciencia Cristiana 4 (1877), s. 289-298, 481-493; č. 5, s. 218-233, 393-410, 481-495.

12 Francisco Pelayo. Darwinism and Paleontology: Reception and Diffusion of the Theory of Evolution in Spain, s. 393. V dané souvislosti si nemůžeme odpustit kritiku nyní vícekrát citované studie F. Pelaya, který tvrdí, že Arintero akceptoval evolucionismus 
dnes by se patrně jenom stěží našel solidní paleoantropolog, který by se odvažoval hovořit o výskytu třetihorního člověka na evropském kontinentu. Oblast možného je však v nálezových vědách vskutku netušeně rozsáhlá, a proto nelze vyloučit, že by v budoucnu k nějakému takovému odhalení mohlo dojít, byt' se to dnes zdá být opravdu velmi nepravděpodobné. Kamenné nástroje nalezené v posledních desetiletích 19. století však určitě ze třetihor nepocházely. Metody datování podobných nálezů byly tehdy ještě značně neuspokojivé.

Sledovat podrobně další peripetie sporů o darwinismus ve Španělsku sedmdesátých a osmdesátých let předminulého století by nebylo ničím jiným než kupením suchých bibliografických údajů. Pro naše účely je však nesmírně důležité, že v devadesátých letech 19. století spory výrazně ztrácejí na své ostrosti. ${ }^{13} \mathrm{~V}$ roce 1909 , konkrétně 22 . února, studenti ve Valencii veřejně slavili sto let od Darwinova narození. ${ }^{14}$ Evoluční koncepce vzniku druhů a do jisté míry také člověka se stále více prosazovala v normálním kurikulu vysokoškolských studií. ${ }^{15}$ Jak uvidíme v tomto i v následujícím příspěvku, k právě popsanému zklidnění situace výrazně přispěli dominikánští myslitelé Zeferino Gonzáles a Juan Gonzáles Arintero, kteří dokázali předložit pro věřícího křestana filosoficky a teologicky přijatelnou interpretaci evolučního vzniku druhů a hlavně člověka, a tak sladit tvrdé údaje přírodních věd s uvědomělou křestanskou vírou.

\section{Dramatické osudy a tematicky bohaté dílo filosofa, biskupa a kardinála Zeferina Gonzálese OP}

I tato druhá část předkládané studie má pouze př́pravný charakter. ${ }^{16}$ Jde nám o porozumění hlavním souvislostem vzniku díla, jímž se budeme v následujícím bodu podrobněji zabývat.

pouze na rovině fauny a flóry, nikoli však na rovině antropologie (srov. tamtéž, s. 394). Jak uvidíme v následující studii, dané tvrzení není přesné, protože podrobný rozbor pramenného materiálu spjatého s Arinterem svědčí ve prospěch výrazně odlišného hodnocení stanoviska tohoto význačného španělského teologa. Opětně se tak potvrzuje opodstatněnost a vědecká přínosnost našeho přístupu, který výrazně upřednostňuje strukturální analýzu příslušných pramenů.

13 Srov. Thomas F. Glick. Darwin en Espaňa, s. 65.

14 Srov. tamtéž, s. 75.

15 Srov. tamtéž, s. 87.

16 Krátkých zmínek o našem autorovi se v přehledové odborné literatuře nachází hned několik, nicméně podrobnější informace o jeho životě nejsou právě nejsnadněji dostupné. $\mathrm{V}$ tomto bodu proto vycházíme z jediného obšírnějšího zpracování, které 
Pozdější bratr dominkán Zeferino (Ceferino - druhá forma jména) Gonzáles y Díaz Tuñon se narodil 28. ledna 1831 ve farnosti San Nicolás de Villona, v provincii Oviedo. Otec Manuel Gonzáles Gonzáles a matka Teresa Díaz Tuñon Blanco byli drobnými zemědělci. ${ }^{17}$

Zeferino Gonzáles vstoupil dne 28. listopadu 1844 v Toledu do noviciátu Řádu bratří kazatelů. První řeholní sliby složil 13. února 1846, tedy jako patnáctiletý. V letech 1846-1848 studoval filosofii v Ocaňa a v květnu téhož roku byl vyslán jako misionář na Filipíny.

Působil v Colegio de Santo Tomás, které od roku 1619, kdy bylo založeno, sloužilo jako př́pravka místních lidí ke křtu. Mladý bratr dominikán tedy pracoval jako misionář a zároveň studoval teologii, kteroužto přípravu dovršil 23. května 1853. Od 12. června 1853 zastával místo lektora filosofie na Univerzitě v Manile, kde přednášel fyziku a následně metafyziku, zároveň však pokračoval ve svém vlastním studiu. Doktorátu filosofie dosáhl 20. listopadu 1855. Kněžské svěcení přijal 28. ledna 1854, tedy přesně v den svých třiadvacátých narozenin. Jak vidno, měl však za sebou velmi mnoho práce a nastřádal již v tomto mladém věku bohaté životní zkušenosti. Dne 20. listopadu 1860 obdržel doktorát z teologie a byl poslán do Colegia de San Juan de Letrán de Manila. Působil taktéž jako horlivý kazatel. ${ }^{18}$ Jeho publikace z oněch let prozrazují velký zájem o prrírodní vědy, sociální nauku a filosofii, ${ }^{19}$ což svědčí o jeho tendenci propojovat teorii s praxí. Dne 5. října 1866

máme k dispozici: srov. Julio Fonseca Rodríguez. Vida de fray Zeferino Gonzáles y Díaz Tuñon. Boletin del Real Instituto de Studios Asturianos LII, 151 (1998), s. 57-85.

17 Sourozenci: José Ramon, narozený 17. ledna 1820, byl také dominikán, profesor filosofie na Colegio San Tomás v Manile v letech 1849-1859, zemřel 29. listopadu 1880; Saturnino, narozený 29. listopadu 1825, rovněž dominikán, kanovník v katedrále v Oviedu, zemřel v Seville 1891; Atanasio de la Cruz, narozený 2. května 1833, byl diecézní kněz, farář, kanovník v Oviedu, zemřel 1894 v Seville; dále Plácido Melitón, narozený 10. března 1837; Zeferino měl dvě sestry: Maríi Teresu, narozenou 5. října. 1823, a Balbinu, narozenou 27. března 1829. Srov. Gustavo Bueno Sánchez. La obra filosófica de Fray Zeferino González. Disertační práce. Universidad de Oviedo 1989, s. 35-40.

18 Srov. tamtéž, s. 59-60.

19 Srov. Los temblores de tierra, 1857 - dílo pojednává o seizmických jevech. La electricidad atmosférica y sus pricipales manifestaciones, 1863 - jak prozrazuje titul, předmětem studia byla atmosférická, statická elektřina. La Economía política y el cristianismo, 1862 - v tomto spisu autor pojednává o sociální nauce církve. Estudios sobre la filosofía de Santo Tomás - vynikající expozice filosofického myšlení Andělského doktora, nejoriginálnější dílo našeho autora z oné doby. Srov. tamtéž, s. 61-62. Pokud se jedná o hodnocení filosofie Z. Gonzálese, srov. Díaz de Cerio. Un cardenal filósofo de la historia. Fray Ceferino Gonzáles O.P. (1831-1894). Roma: Libreria Editrice della Pontificia Università Lateranense 1969. Zabýval se nejen ontologií, ale také kosmologií, psychologií, ideologií, morálkou a politikou v duchu sv. Tomáše. Nebyl pouhým 
si v dopise svému představenému do Španělska stěžoval, že velkou překážku v dalším působení na Filipínách představuje jeho neutěšený zdravotní stav. Dostal tedy svolení k návratu do Španělska. Odjel z Filipín a v roce 1867 přes Hongkong, Egypt a Marseille dospěl konečně do Barcelony. ${ }^{20}$ Jestliže do Filipín se dostal přes Atlantik a Tichý oceán, pak při návratu do vlasti dokončil cestu kolem světa.

Po návratu ne zcela zdravý dominikán rozhodně neztrácel čas, a tak o rok později, tedy již v roce 1868, vydal v Madridu přepracovanou verzi svého díla o moderní aplikaci filosofických principů Tomáše Akvinského Philosophia elementaria, kterážto kniha pak sloužila jako studijní text na řadě univerzit, konkrétně na Filipínách, ve Španělsku, Francii, Itálii, Německu, Polsku, dokonce i v Rusku. ${ }^{21}$

V roce 1869 předložil jasnozřivý návrh, aby vznikla ediční řada španělské teologie, konkrétně se jedná o esej Sobre una biblioteca de los teologos espaňoles. Právě připomenutý záměr došel naplnění až v roce 1930. Období let 1868 až 1875 (září 1868 - 29. prosince 1875), jak již víme, byla dobou revoluce, jejíž zaměření bylo výrazně antikatolické. ${ }^{22}$ Není tudíž nesnadné konstatovat, že pro otce Gonzálese to nebyla právě snadná kapitola jeho života. Pobýval v konventu de la Passion v Madridu, kde sídlila pokuratura misionářů dominikánů na Filipínách. Zde se kolem něho utvořila skupina studentů, jimž přednášel filosofii a zasvěcoval je i do jiných věd, konkrétně do fyziky, psychologie, politiky atd. V roce 1873 vydal soubor svých prací, které předtím publikoval v různých periodikách: Estudios religiosos, filosóficos, cientificos y sociales. ${ }^{23}$

Dne 21. srpna 1873 byl Zeferino Gonzáles jmenován rektorem Colegia de San Juan de Letrán v Manile, které bylo založeno již v roce 1640, a to původně jako škola pro základní vzdělání, později se zde studentům dostávalo středoškolského humanitního vzdělání. Papežský nuncius Bianchi měl však jiné plány, protože ho trápila závažná potřeba španělské místní církve obsadit šest uprázdněných biskupských stolců. Na konzistoři 16. ledna 1874 ve Vatikánu Pius IX. ustanovil našeho autora biskupem v Malaze. To ale bylo proti mysli revoluční vlády, a tak

komentátorem, jelikož se pokoušel tvůrčím způsobem propojovat tomismus s moderní vědou.

20 Srov. Julio Fonseca Rodríguez. Vida de fray Zeferino Gonzáles y Díaz Tuñon, s. 63.

21 Srov. Cesáreo Rodríguez Garda Loredo. Una gloria de Asturias. El Cardenal Fray Ceferino Gonzáles. Región, 26. 2. 1931, s. 2.

22 Srov. Julio Fonseca Rodríguez. Vida de fray Zeferino Gonzáles y Díaz Tuñon, s. 65.

23 Srov. tamtéž, s. 68. 
Zeferinu Gonzálesovi nezbylo nic jiného než na nominaci rezignovat. Když však v roce 1875 došlo k obnově monarchie a nastoupil panovník Alfonso XII., mohl být konečně dominikánský učenec v Královském kolegiu svatého Dominika v Ocaňa vysvěcen dne 24. října 1875 na biskupa a následně se ujmout správy diecéze Córdoba. Jeho světitelé byli všichni dominikáni povýšení na biskupské stolce, hlavním světitelem byl opět dominikán, kardinál, arcibiskup ze Zaragozy Manuel García Gil. Nový biskup se pustil do práce s velkou vervou: reorganizoval seminář, z hlediska našeho zájmu není bez významu, že modernizoval muzeum dějin prrírody, dbal na vědeckou přípravu kléru, organizoval svolání diecézní synody, věnoval nemalou pozornost sociální otázce a charitativnímu dílu církve. ${ }^{24}$ Je patrné, že aktivity nového biskupa úzce souvisely s jeho odbornými zájmy z předchozích let.

V době ostrých sporů o darwinismus založil periodikum La Ciencia Cristiana, o němž již byla řeč. V letech 1878 až 1879 vydal v Madridu čtyřsvazkové dílo Historia de la Filosofía, které se dočkalo reedice v roce 1886 a následně 1907 a je ve Španělsku považováno za klasické. ${ }^{25}$

V listopadu 1881 založil ve své nové diecézi katolickou antiliberální politickou stranu Unión Católica, čímž se dostal do sporu s tradicionalistickou stranou. Ke smíru došlo po ostrých polemikách až 17. dubna 1883. Dne 3. června téhož roku byl Zeferino Gonzáles přijat za člena institutu Real Academia de Ciencias Morales y Políticas, mimoto participoval také na činnosti ústavu Real Academia de la Historia a také Real Academia Espaňola de la Lengua. Dne 22. ledna 1883 prezentoval španělský panovník Alfonso XIII. Zeferina Gonzálese jako kandidáta na uprázdněný arcibiskupský stolec v Seville. ${ }^{26}$

Dne 10. listopadu 1884 papež Lev XIII. prohlásil Zeferina Gonzálese za kardinála svaté církve římské s titulem Santa Maria de la Minerva. Slavnostní prohlášení se odehrálo ve Španělsku 14. listopadu v královském paláci v Madridu za účasti krále Alfonsa XIII. Odevzdání kardinálských insignií z rukou Lva XIII. se uskutečnilo dne 17. března 1885 ve Vatikánu. ${ }^{27}$

Dne 14. února 1885 vláda Alfonsa XIII. prezentovala Zeferina Gonzálese jako kandidáta na stolec španělského primase v Toledu, kde

\footnotetext{
24 Srov. tamtéž, s. 69-70.

25 Srov. Carlos Valverde. Los cattólicos y la cultura espaňola. In: Historia de la Iglesia en Espaňa contemporanea (1808-1878). Madrid: BAE 1979, s. 465-525, zde 518.

26 Srov. Julio Fonseca Rodríguez. Vida de fray Zeferino Gonzáles y Díaz Tuñon, s. 74.

27 Srov. tamtéž, s. 74-75.
} 
zemřel kardinál Moreno. Působení našeho autora v Toledu však trvalo jen krátce, jednak kvůli kardinálovu chatrnému zdraví, jednak kvůli tomu, že jeho nástupce na stolci v Seville Bienvenido Monzón náhle zesnul. Dne 9. března 1886 bylo rozhodnuto, aby se Zeferino Gonzáles vrátil do Sevilly. V květnu 1889 prezentoval práci věnovanou tématu La antigüedad del hombre y la prehistoria (Stáří člověka a prehistorie). V září 1889 byl však nucen rezignovat na všechny své úřady kromě onoho kardinálského, protože jeho zdravotní stav se výrazně zhoršil. Pak až do smrti pobýval v Castilleja de Cuesta, zde se kdysi narodil dobyvatel Hernán Cortés.

Ač velmi vážně nemocen, usilovně dál pracoval na poli vědy, a tak v posledních letech jeho života vzniklo velmi obsáhlé, dvousvazkové dílo La Biblia y la Ciencia, jímž se budeme podrobně zabývat ve třetím bodu této studie. Kniha poprvé vyšla v roce 1891 a vyvolala obrovský zájem, pročež druhá edice následovala hned následujícího roku. ${ }^{28}$

Velmi důležitý je údaj, podle něhož tímto spisem náš autor na vysoké odborné úrovni reagoval na z dřívějšího bádání známý, ostře antikřestansky laděný spis či spíše hanopis Johna Williama Drapera, ${ }^{29}$ který vyšel v překladu do kastilštiny v Madridu roku 1876, tedy rok po obnově monarchie, a podruhé v roce 1885 se španělským titulem Historia de los coflictos entre la Religión y la Ciencia (Dèjiny konfliktů mezi náboženstvím a vědou). Španělský kardinál a arcibiskup v době své nemoci velmi fundovaně dokládal, že mezi vírou a vědou není konflikt ani rozpor. On sám se zcela po právu představuje jako muž víry i vědy. ${ }^{30}$

Ve zpracování života našeho autora, na něž jsme výše vícekrát odkazovali, se nachází následující souhrnná charakteristika Gonzálesových postojů: odmítal vnímat Mojžíšův popis vzniku kosmu v literárním smyslu; přijímal Laplaceovu teorii, byl velmi otevřený vůči objevům

28 Srov. tamtéž, s. $76-77$.

29 Kniha vyšla v témže období také v českém překladu: srov. J. W. Draper. Dějiny konfliktů mezi náboženstvím a védou (překl. S. Mokrý a T. Sokol). Praha 1875-1891 (?). Originál: History of the Conflict between Religion and Science. New York: D. Appleton 1874. Určitě není bez zajímavosti, že fundovaná a mnohočetná reakce španělských katolických myslitelů na zmíněný titul nalezla ohlas i v českém prostředí díky překladové studii: T. T. Cámara (světící biskup toledský). Náboženství a véda (překl. Antonín Grep a V. Kotrba). Praha 1903. Tento recenzní spis vyšel rovněž na pokračování v periodiku ČKD 3 (1903), s. 203-206; ČKD4 (1904), s. 264-267; ČKD 5 (1904), s. 326-327. Španělský autor odmítal aplikaci evolučního modelu na vznik člověka. s. XXXVII. 
geologie a paleontologie; kritizoval darwinismus, nezavrhoval ho však jako celek; snažil se harmonizovat darwinismus s biblickým vyprávěním o stvoření, a to i na antropologické rovině; vědecky dokazoval jednotu lidského rodu; pohlížel novýma očima na stáří lidského rodu, když se odklonil od tradičního katolického pojetí této otázky. Jeho př́stup k biblickému textu rozhodně nebyl fundamentalistický. Jasně rozlišoval mezi biblickou exegezí, která je hledáním pravdy, a pravdou samotnou. ${ }^{31}$

Vrat'me se ale ještě stručně k posledním letům kardinálova života. V dané souvislosti se zdá být vhodné rekapitulovat vývoj jeho zdravotního stavu. Při svém pobytu na Filipínách trpěl silnými horečkami a silnou bronchitidou. V roce 1866 dokonce přijal svátost nemocných, protože se zdálo, že umírá. To byl také důvod jeho návratu do Španělska. Dlouhodobě ho trýznil revmatismus. V roce 1886 se začaly projevovat první příznaky onemocnění rakovinou, což byl také důvod, proč opustil biskupský stolec. Pomazání nemocných přijal dne 20. listopadu 1894 a zesnul 29. listopadu téhož roku. Před smrtí se vrátil do Madridu, do konventu de la Passion, kde v cele číslo 15 očekával smrt. Pohřeb se odehrál v katedrále sv. Isidora v Madridu dne 6. prosince 1894 v deset hodin dopoledne. ${ }^{32}$

Budiž nám dovoleno vyslovit obdiv nad rozsahem i kvalitou díla tohoto muže, který to vše vytvořil navzdory svému chatrnému a stále se zhoršujícímu zdravotnímu stavu. Duchovní pohled na dané skutečnosti vede věřícího hodnotitele k závěru, že právě ve slabosti se projevující síla nemohla být pouze lidského původu. Zeferino Gonzáles byl filosofem, teologem, přírodovědcem i mužem akce. Jeho názory měly velkou váhu nejen mezi odborníky, ale především v církevním prostředí, a to kvůli jeho duchovnímu životu i vysokému úřadu, který zastával. Je to jediný kardinál římské církve oněch desetiletí, který sepsal obdobně laděný apologetický spis, v němž se projevovala otevřenost možnosti evolučního vzniku lidského těla. A právě tyto údaje se nyní pokusíme prověřit a upřesnit na základě analýzy poslední velké monografie Zeferina Gonzálese. Spisem La antigüedad del hombre y la prehistoria se zabývat detailněji nebudeme, protože je evidentní,

31 Srov. Julio Fonseca Rodríguez. Vida de fray Zeferino Gonzáles y Díaz Tuñon, s. 79-80.

32 Srov. tamtéž, s. 82-84. Srov. Gustavo Bueno Sánchez. La obra filosófica de Fray Zeferino González, s. 90-94. 
že názory z tohoto díla se budou projevovat v pozdějším spisu, do jehož četby se nyní ponoříme.

\section{Analýza vybraných pasáží díla La Biblia y la Ciencia z roku 1891}

Víme již, že základní pohnutka, která vedla našeho autora k sepsání díla, má výrazně apologetickou povahu. Jednalo se o obhajobu rozumové dimenze víry, vycházející z biblického zjevení tváří v tvář její dehonestaci ze strany materialistů, ateistů a monistů, kteří k tomuto účelu využívali objevů prírodních věd. ${ }^{33}$ Víme také, že Z. Gonzáles nevystupuje pouze jako teolog, ale hlásí se rovněž k přírodovědcům, protože sám na tomto poli editoval nejedno dílo. Práce tohoto druhu byla opravdu velmi naléhavá, nebot' generace posledních desetiletí 19. století v celé Evropě prožívaly napětí mezi vírou a př́rodními vědami vskutku dramaticky. Mnohdy nešlo pouze o víru v její věroučné čistotě a o příslušnost k církvi, ale dokonce $\mathrm{v}$ pravém slova smyslu o život. ${ }^{34}$

Jelikož dvousvazkové dílo španělského kardinála je vskutku velmi rozsáhlé, musíme naši prezentaci s určením pasáží, jimž budeme věnovat zvýšenou pozornost, rozdělit na dvě části. V první z nich se budeme zabývat prvním svazkem v titulu tohoto oddílu uvedeného spisu, ve druhé druhým svazkem.

33 Jméno Draper s odkazy na jeho názory se v prvním svazku objevuje na stranách 140, 365, 366, 370, 372. V prologu se setkáváme se jmény Büchner, Vogt, Haeckel, Huxley (s. XXXVI).

34 Materialistické pojetí př́rodovědy totiž přivedlo nejednoho člověka posledních desetiletí předminulého století až k nihilismu, který mohl snadno vyústit v sebevraždě. Víra v Boha a v Krista se pak mnohým po strašných vnitřních krizích jevila jako garance smysluplnosti života, jako záchrana před dobrovolným odchodem ze života, nicméně církevní háv této víry se mnoha vzdělancům jevil jako těžko přijatelná alternativa. Srov. např. T. G. Masaryk. Rusko a Evropa III. Studie o duchovnich proudech v Rusku. Praha: Ústav T. G. Masaryka 1996, s. 349-287. Z našeho hlediska je rovněž pozoruhodné, že český profesor filosofie a od roku 1918 také první prezident Československa vnímal nejen $\mathrm{v}$ uvedeném svazku, ale $\mathrm{v}$ zásadě $\mathrm{v}$ celém svém díle toto napětí přednostně na světonázorové a filosofické rovině, nikoli tolik jako konflikt mezi vědou a náboženstvím, abychom zůstali věrni jeho terminologii. I on se ale vnitřně nedokázal ztotožňovat s církevní formou víry a věroučnou stránkou křestanství. Rovněž Masaryk velmi usilovně bojoval o náboženský rozměr své existence, který chtěl sladit $\mathrm{s}$ poctivou vědeckostí. Identické drama se pochopitelně v různých obměnách a na nesčetných rovinách jako dědictví po minulých generacích nemůže neodehrávat i v našich životech. 


\subsection{Analýza vybraných partií z díla Cardenal Gonzáles. La Biblia y la Ciencia 1. Imprenta de A. Pérez Dubrull. Madrid 1891, XLVII, 613 stran}

Jak je dobrým obyčejem, nejprve seznámíme s celkovou strukturou svazku, představeného v titulu tohoto pododdílu. Po prologu (s. I. LXVII) následuje celkem jedenáct kapitol. První z nich pojednává o vnímání Bible v katolickém prostředí (s. 2-44), druhá představuje protestantské pojímání inspirovaného textu (s. 45-138). Následuje představení toho, čím je věda (s. 139-186). Čtvrtá partie spisu je věnována obecným charakteristikám poměru mezi Biblí a vědou (s. 187250). Šestá pasáž pojednává o moderní vědě a náboženské pravdě biblického hexaemeronu (s. 295-316). Následuje téma hexaemeron a astronomie (s. 317-340). Poté se hovoří o biblickém hexaemeronu a fyzikálních vědách (s. 341-364). Dalším tématem je objasnění poměru mezi biblickým hexaemeronem na jedné straně a přínosy moderní geologie (s. 365-392). Zajímavá je desátá kapitola, v níž se vyhodnocuje teorie katolického biskupa Clifforda, který chápal zprávu o stvoření v první kapitole knihy Genesis jako hymnus, v němž se k jednotlivým dnům v týdnu přiřazují díla stvoření, za něž je třeba vzdávat Hospodinu díky (s. 393-417). Popis stvoření je tudíž podle Clifforda vlastně odrazem hypotetické týdenní slavnosti stvoření v jeruzalémském chrámu. Vzhledem k našemu hlavnímu zájmu není nesnadné uzavřít, že svou pozornost budeme nyní věnovat poslední, jedenácté kapitole daného svazku, v němž se hovoří o biblickém hexaemeronu a biologii, což zahrnuje rovněž problematiku darwinismu (s. 418-613).

Nyní ke struktuře jedenácté kapitoly. V oddílu 11. I se pojednává o darwinismu z hlediska jeho originality a původu (s. 418-434). Druhá část (11. II) je věnována problematice poměru darwinismu k biblickému zjevení (s. 435-489). Ve třetí pasáži (11. III) jedenácté kapitoly náš autor zkoumá antropologický rozměr darwinistické hypotézy (s. 490-526). Ve čtvrté (11. IV) pak posuzuje slučitelnost těchto idejí s biblickým zjevením (s. 527-553). Následuje pátý krok (11. V), v němž Z. Gonzáles zkoumá otázku slučitelnosti darwinismu s učením církve o vzniku lidské duše. Konečně v šestém oddílu jedenácté kapitoly (11. VI) předkládá závěrečnou kritiku darwinistické hypotézy (s. 554-613).

Mělo by být zřejmé, že na tomto místě lze prezentovat pouze to nejzásadnější z obsahu celé jedenácté kapitoly prvního dílu spisu La Biblia y la Ciencia. 
Pokud jde o darwinismus na rovině fauny a flóry, je třeba v první řadě konstatovat, že Z. Gonzáles měl dokonalý přehled nejen v oblasti teologie, ale také přírodovědeckých studií věnovaných dané problematice, a to na široké mezinárodní platformě. Je evidentní, že kardinál katolické církve a vynikající tomista musí odmítnout všechny ideologicky laděné interpretace transformismu a evolucionismu materialistického, ateistického a monistického zaměření jako něco, co není a nemůže být přírodovědecky prokázáno.

Naproti tomu ale na základě myšlenek sv. Augustina a sv. Tomáše Akvinského vnímá jako s Písmem velmi dobře harmonizovatelnou koncepci spontánního vzniku živých tvorů z neživé materie. ${ }^{35}$ Velmi pozitivně pak hodnotí příbuzenství mezi druhy fauny a flóry i jejich postupně stále dokonalejší formy, vycházející z předchozích méně dokonalých.

[P]okud se jedná o ustavičný a uspořádaný proces nebo pochod po stupních bytí, zejména pak o bytosti obdařené životem, pak je nepopiratelné, že tím vším z hloubi přímo dýchá mojžíšovské vyprávění, v němž se nám předkládá stvořitelské působení Boha, který produkuje jsoucna skládající universum vzestupným způsobem, když přechází od chaotické hmoty ke hvězdám, Zemi a mořím, od toho všeho ke světlu, k rostlinám, živočichům a nakonec k člověku, který je dovršením a korunou viditelného tvorstva. ${ }^{36}$

Ačkoli v předchozích pasážích vyjádřil náš autor pochybnosti ohledně mechanismů evoluce, jak je popisuje Ch. Darwin, protože nejsou vědecky prokázané, samotný transformismus a vzestup kvality tvorů v čase rozhodně nepopírá. Transformismus a v jistém slova smyslu také evoluce v oblasti života není podle něj v rozporu s biblickou zprávou o stvoření. Velmi důležité je, že již na tomto místě nevylučuje ze vzestupného procesu života ani člověka. Je ovšem pochopitelné, že

35 Srov. Cardenal Gonzáles. La Biblia y la Ciencia 1. Imprenta de A. Pérez Dubrull. Madrid 1891 , s. $463-464$.

36 „... de progreso continuo ó marcha ascendente y ordenada en la escala de los seres, y determinadamente de los seres dotados de vida, es incontestable quo esta última palpita en el fondo de la narración mosaica, en la cual se nos presenta la acción creadora de Dios produciendo los seres que componen el universo, en gradación ascendente, pasando de la materia caótica á los astros, la tierra y los mares, de éstos á la luz, á las plantas, á los animales, y, por último, al hombre, término, complemento y como corona de las criaturas visibles.“ Tamtéž, s. 488. 
primární, stvořitelskou příčinou všech věcí a jevů je Stvořitel, Hospodin. ${ }^{37}$ Právě v tom, že se opomíjí tato primární, stvořitelská příčina, tkví základní bod kritiky darwinismu.

Je však třeba podotknout, že Hospodin není prostou příčinou účinnou, která by se nesnadno dala zahlédnout ve zkumavce nebo v paleontologickém „zápisu“. Tato prvoprvá, stvořitelská příčina používá stvořených jsoucen a daností jako př́ičin, které mohou působit na první pohled jako téměř účinné. Rozhodně musíme hodnotit jako velmi správné, že Z. Gonzáles nehovoří o Bohu jako o prosté účinné příčině transformistického pohybu. ${ }^{38}$

Pokud se jedná o člověka, španělský dominikán jasně podtrhuje, že přinejmenším lidská duše musí být stvořena bezprostředně Bohem. ${ }^{39}$ Podstatné je, že totéž se absolutním způsobem netvrdí o lidském těle. Je tudíž zcela konsekventní, když Z. Gonáles jasně odmítá darwinistickou tezi, podle níž by lidská duše měla vzniknout cestou samovolné evoluce, protože dané tvrzení nelze prokázat na rovině př́írodovědy nebo paleoantropologie. ${ }^{40}$ Dodáváme, že na př́rodovědecké rovině není možno onu tezi o čistě evolučním původu lidské duše či psychiky ani vyvrátit, nebot se jedná o světonázorově a filosoficky laděné vnímání vlastního obsahu lidství, tedy o světonázorovou sebeinterpretaci vlastní lidské existence, která má ovšem celou řadu dalekosáhlých důsledků v oblasti etiky, postoje k náboženství a v celé škále hodnot, které jsou pro důstojné lidství konstitutivní.

Vzhledem k vlivu myšlení A. Rosminiho, který je prokazatelný téměř u všech italských průkopníků evoluční koncepce vzniku - stvoření člověka, jistě nesmí uniknout našemu zájmu, že mezi různými koncepcemi lidské duše Z. Gonzáles zmiňuje rovněž tezi A. Rosminiho. Tento nesporně vynikající a dnes také blahořečený katolický myslitel se domníval, že rodiče předávají potomkovi nejen tělo, ale také smyslovou duši. Ta je pak přímo Bohem prostřednictvím určitého specifického osvícení povznesena na rovinu duše racionální. Z. Gonzáles právě uvedenou koncepci odmítá na základě Tomášovy teze, podle níž

\footnotetext{
Srov. tamtéž, s. 527.

38 Při zkoumání celého předmětného spisu jsme nenašli formulaci, která by o Bohu mluvila jako o účinné přičině a o evoluci jen jako o příčině materiální celého vývojového procesu. V některých interpretacích díla Z. Gonzálese se takováto formulace vyskytuje a je našemu autorovi přisuzována.

39 Srov. tamtéž, s. 521.

40 Srov. tamtéž, s. 534.
} 
žádná věc nemůže změnit svou esenci jen na základě proměny akcidentální formy nebo kvality. ${ }^{41}$ Osvícení je opravdu pouze akcidentální změnou, a proto díky němu nemůže být smyslová duše proměněna $\mathrm{v}$ duši rozumovou.

Jestliže evoluční vznik lidské duše je pro španělského dominikána absolutně nepřípustný, o možnosti vzniku lidského těla už tak jednoznačně zamítavý soud nevyslovuje.

Lze připustit, aniž bychom tím překračovali meze biblické exegeze, a především bez toho, že bychom upadli do heretického tvrzení, že lidské tělo prvního člověka nabylo, anebo alespoň mohlo nabýt svého organického uspořádání, které bylo vhodné pro přijetí racionální duše, prostřednictvím nějakého předchozího vývoje, a to cestou transformace nebo postupné evoluce z jiného organismu. (...) To, že obdobnou teorii nebo způsob vysvětlování původu a formování Adamova těla nelze hodnotit jako cosi protikladného vzhledem ke zjevení, můžeme vyvodit z toho, že církev až dodnes neodsoudila ani neprohlásila na poli křestanského myšlení za nepřijatelné Mivartovo mínění. ${ }^{42}$

Lidské tělo tedy mohlo vzniknout cestou transformace z určitého živočišného druhu, tedy lidoopa. Podle Z. Gonzálese by bylo velmi hrubou nespravedlností hodnotit Mivartovu tezi jako součást vyhraněného darwinismu, protože mezi oběma př́stupy je zásadní rozdíl v pojetí vzniku lidské duše. ${ }^{43} \mathrm{Z}$. Gonzáles má však zároveň k původní verzi Mivartovy teze výhrady, protože podle tradičního učení i tělo prvního člověka bylo stvořeno př́mo Bohem. ${ }^{44} \mathrm{~V}$ pozadí je pochopitelně rovněž problém nemožnosti existence lidského těla $\mathrm{v}$ generaci před oduševněním bez lidské duše, protože by to odporovalo nauce o duši jako podstatné formě těla. Španělský kardinál v daném kontextu připomíná, že svatý Tomáš Akvinský připouštěl předchozí přípravu ještě ne zcela

41 Srov. tamtéž, s. 567-570.

42 „Puede admitirse, sin violentar la exegesis bíblica, y sobre todo sin incurrir en sentencia herética, que el cuerpo humano del primer hombre adquirió, ó al menos pudo adquirir las condiciones orgánicas convenientes para recibir el alma racional por medio de un desarrollo anterior, por medio de una transformación ó evolución progresiva de otro organismo... Que semejante teoría ó modo de explicar y entender el origen y formación del cuerpo de Adán no puede calificarse de contrario á la revelación, parece deducirse del hecho que la Iglesia no ha reprobado hasta hoy, ni ha declarado inadmisible en el terreno cristiano, la opinión de Mivart.“ Tamtéž, s. 542. Srov. tamtéž, s. 546-547.

44 Srov. tamtéž, s. 543. 
lidského těla ze strany andělů, z něhož pak Bůh stvořil vlastní lidské tělo. ${ }^{45}$

Dospíváme tak k modifikaci Mivartovy teze, která je velmi podobná té, s níž ve stejném roce vystoupil francouzský dominikán M. D. Leroy. ${ }^{46}$ Oba dominikánští myslitelé tudíž ve stejném čase do jisté míry dospěli paralelně k velmi obdobnému řešení.

Z. Gonzáles se domnívá, že Mivartova teze rozhodně není v rozporu se zjevením a také se neprotiví nauce církve. Nicméně se tu objevují problémy, ${ }^{47}$ protože například tradiční exegeze, byt' v tomto ohledu není jednotná, hovoří o přímém stvoření lidského těla Bohem. Určitě je zde ve hře také problém jednoty lidské bytosti, která se vyjadřuje naukou o duši jako podstatné formě těla. Dané problémy lze ale odstranit následujícím vylepšením:

Tyto těžkosti zmizí, nebo se alespoň minimalizují, propojíme-li Mivartovu tezi s myšlenkou, již poznamenává sv. Tomáš ohledně možného spolupůsobení př́íčin nebo činitelů odlišných od Boha při formování Adamova těla, případně při předběžné př́pravě téhož těla, což ladí s více či méně vysokým stupněm rozvoje. Musíme však vždy připisovat Božímu zásahu poslední přípravu organické dispozice [tohoto těla] k přijetí rozumové duše. Tímto způsobem se v souladu s koncepcí Andělského učitele uchová základ Mivartovy hypotézy a zároveň zůstane bez újmy přímé a bezprostřední Boží působení při formování těla prvního člověka, jak to vyžaduje tradiční výklad biblického textu. ${ }^{48}$

Rozhodně bychom neměli podceňovat, že tyto myšlenky publikoval arcibiskup a kardinál katolické církve. Neexistuje žádný vyšší oficiální

45 Srov. tamtéž, s. 548. Odkazuje se na Com. Sent II, dist. 18, q. 1, a.2.

46 Srov. M. D. Leroy. L'Évolution restreinte aux espèces organiques. Paris - Lyon: Delhomme et Briguet 1891, s. 267.

47 Srov. tamtéž, 549-550.

48 „Estos inconvenientes desaparecen, ó se atenúan al menos, poniendo en contacto y relación la hipótesis de Mivart con la idea que apunta Santo Tomás acerca de la posibilidad de quo causas ó agentes distintos de Dios hayan intervenido en la formación del cuerpo de Adán, ó sea en la preparación previa del mismo, hasta llegar á un grado más ó menos perfecto de desarrollo, pero reservando siempre á la acción de Dios la preparación última y corno la disposición orgánica próxima para recibir el alma racional. De esta manera, y según esta concepción del Doctor Angélico, se salva el fondo de la hipótesis de Mivart, sin perjuicio de la acción directa é inmediata de Dios en la formación del cuerpo del primer hombre, acción que parece exigir la exegesis bíblica tradicional.“ Tamtéž, s. 550. 
představitel katolické církve, který by se $\mathrm{v}$ dané době takto otevřeně zastal Mivartovy teze a zároveň ji rozvinul takovým zpo̊sobem, aby byla nejen v souladu s tradičním výkladem prvních dvou kapitol knihy Genesis, ale i s naukou Tomáše Akvinského. Když dva dělají totéž, nebývá to okolím hodnoceno stejným metrem. Posuzovat kardinála si jen tak někdo netroufne, zvláště když jsou jeho argumenty velmi jasné a logické, filosoficky i teologicky „neprůstřelné“. Jakmile ale v podstatě totéž vyjádří sice velmi vzdělaný, ale přece jenom pouze řeholník a kněz, útoky se $\mathrm{v}$ oné době daly očekávat, což se naplnilo v případě M. D. Leroye OP ${ }^{49}$ Zároveň se potvrzuje naše tušení, totiž že Leroyova kniha vyjadřovala nejenom jeho osobní postoj, ale do jisté míry vyznívala jako výraz mínění vícero francouzských dominikánů a souzněla také s míněním význačných španělských dominikánů v devadesátých letech předminulého století.

\subsection{Analýza vybraných partií z díla Cardenal Gonzáles. La Biblia y la Ciencia 2. Imprenta de A. Pérez. Madrid: Dubrull 1891, 683 stran}

Jestliže v první knize autor pojednával o metodologických předpokladech vyjasňování poměru mezi Biblí a vědou, následně o astronomii, geologii a biologii, zejména pak o darwinismu, pak v druhém svazku se zaměřuje na antropologické problémy přednostně v souvislosti s geologií a prehistorickou archeologií. Hlavní tematické okruhy vcelku jasně vysvítají z titulů čtyř kapitol. První z nich je věnována problematice lidského druhu podle vědy a podle Bible (s. 5-226). Hlavní otázkou, kolem níž vše krouží, je jednota lidského rodu. Ve druhé kapitole Z. Gonzáles řeší problém stanovení stáří lidského rodu (s. 227-260). V následující partii pokračuje bádání nad dobou trvání lidského rodu, tentokrát z hlediska „geologie“ (s. 261-528), dnes bychom spíše použili výrazu prehistorická archeologie nebo paleoantropologie. V poslední části se hovoří o problematice potopy (s. 529-685).

49 Srov. M. Artigas - Th. Glick - R. A. Martínez. Negotiating Darwin, the Vatican Confronts 1877-1902. Baltimore: The Johns Hopkins Press 2006, s. 52-123. Otázkou je, proč právě uvedení autoři na paralelu mezi Leroyem a Z. Gonzálesem neupozorňují. Není také jasné, proč se M. D. Leroy při své obhajobě neodvolával na svého španělského spolubratra. Zároveň je ale třeba přiznat, že útok na dílo francouzského dominikána nebyl veden přímo proti Mivartově tezi, ale jaksi oklikou na jeho domněle nepřiměřenou exegezi biblického textu. 
První kapitola, jak již bylo řečeno, je obhajobou jednoty lidského druhu, s čímž jde ruku v ruce odmítání nauky o vyšších a nižších lidských rasách. Hned na začátku se autor zabývá otázkou, zda lidstvo pochází z vícero jedinců. Lékaři a paleontologové se kloní spíše k polygenismu. Podstatná je pouze jednota lidského rodu, ${ }^{50} \mathrm{kterou}$ Z. Gonzáles obhajuje dobře známými argumenty v celé této kapitole. Monogenismus je důležitý z náboženských důvodů, což se objasňuje v závěrečném oddílu první kapitoly, kde se dozvídáme, že monogenismus hraje velkou roli v nauce o prvotním hříchu a dědičné vině. ${ }^{51}$

Je určitě podnětné, když Z. Gonzáles hovoří o objevech neandrtálců a tvrdí, že jejich lebky jsou plně lidské, ${ }^{52}$ což mimochodem zcela odpovídá dnešnímu paleoantropologickému hodnocení statusu těchto inteligentních bytostí. Dále se dozvídáme, že ti, kdo věřili na počátku devadesátých let 19. století v existenci opočlověka, nemohli zatím poskytnout žádný relevantní důkaz. ${ }^{53} \mathrm{~V}$ roce 1891 toto hodnocení skutečně platilo, protože E. Dubois přišel se svým pitekantropem až o několik let později, přičemž o jeho objevu na Jávě se vedly několik let trvající vědecké spory.

Druhá kapitola obsahuje rozvahu zejména o závaznosti biblické datace stář́ lidstva na základě věku patriarchů. Gonzálesova kritičnost a vědeckost je patrná z jasného odmítání závaznosti biblické datace, a to na základě exegetických principů, jež spatřuje v díle sv. Augustina a sv. Tomáše. ${ }^{4}$ Jisté je pouze to, že člověk se v historii kosmu a Země objevuje relativně nedávno a že jeho vstupu na scénu předcházely velmi dlouhé epochy. Následně jmenuje celou řadu katolických teologů, kteří zaujímali obdobné stanovisko. ${ }^{55}$ Kritické myšlení nedovoluje španělskému dominikánovi spekulovat o osmi nebo deseti tisíci letech trvání lidského rodu, prostě nechává otázku otevřenou a potvrzuje, že

50 Srov. Cardenal Gonzáles. La Biblia y la Ciencia 2. Imprenta de A. Pérez. Madrid: Dubrull 1891, s. 13-17.

51 Srov. tamtéž, s. 197-226.

52 Srov. tamtéž, s. 74 .

53 Srov. tamtéž, s. 75-76.

54 Srov. tamtéž, s. 242.

55 Jmenováni jsou: kardinál Wisemann, arcibiskup z Tours Metan, jezuité Pianciani a Perrone, angličané Buckland, Chalmers, Miller a Molloy, dále oratoriáni Valroger a Motais, Vigouroux a Donillard ve Francii, američtí profesoři Silliman a Dana, dále Kurtz, Reich a mnozí němečtí teologové. V̌sichni se hodují v tom, že vstupu člověka na scénu světa předcházely nesmírně dlouhé epochy s mnoha nejrůznějšími geologickými a klimatickými zvraty. Srov. tamtéž, s. 242-243. 
biblické údaje ohledně věku patriarchů nejsou v této věci pro věřícího katolíka žádnou překážkou.

Třetí kapitola druhého svazku je nejenom velmi rozsáhlá, ale také nesmírně zajímavá, protože se zde projevuje postoj kritického teologa a filosofa k dobovým údajům paleoantropologie. Z. Gonzáles jednoznačně upřednostňuje pravdu při obhajobě neudržitelných názorových pozic. Jestliže tedy geologie a paleontologie v souzvuku s astronomií dokládají výrazně jinou dataci, než je ta, kterou lze vyčíst z Bible, pak je nezbytné opustit většinové mínění dávných exegetů a teologů. Španělský kardinál a filosof však ve své době zcela oprávněně konstatuje, že mezi geology a paleontology panuje velká rozrůzněnost ohledně stanovení absolutního stáří lidstva, a proto je třeba tuto otázku nechat prozatím otevřenou. ${ }^{56}$ To nesporné je však třeba akceptovat, a proto náš autor přijímá údaje o ledových dobách a uctivě se zmiňuje o Leyllovi. ${ }^{57}$

Hypotéza existence třetihorního člověka nebyla v roce 1891 prokázána, a proto ji Z. Gonzáles nemůže akceptovat. ${ }^{58}$ Je evidentní, že prehistorické nástroje, které měly dokladovat třetihorního člověka v Evropě by ani podle dnešních datačních metod nic takového neprokazovaly. Zároveň by asi bylo sporné označovat dnes známé hominidy $\mathrm{z}$ konce třetihor za lidi $\mathrm{v}$ dnešním slova smyslu. Zároveň je $\mathrm{v}$ jistém slova smyslu obdivuhodné, že náš autor se neopovažuje vyslovovat nějaké definitivní soudy o nemožnosti existence hominidů v dávných epochách: „Pole možného je velmi rozsáhlé, a proto by bylo neopatrné stanovovat mu nějaké meze především tehdy, když se jedná o problém spjatý s empirií. ${ }^{59}$

Z našeho hlediska je určitě velmi přínosné, když nás španělský dominikán zpravuje o dalších katolických autorech, kteří se vyslovovali pozitivně o předchůdcích člověka ve třetihorách.$^{60}$ Jedná se například o oratoriána P. Valrogera, který ve své knize L'áge du monde et de l'homme d'aprés la Bible et l'Eglise hovořil na straně 144 o předchůdcích člověka, z nichž Bůh pak stvořil naše prapředky. Další je dominikán, slavný kazatel P. Monsabré, jenž ve svých konferencích Conf. á Notr. Dam. 1875 rovněž hovořil o stupňovitém vzestupu směrem k člověku a o možnosti třetihorních předlidí. Tím by se opětně

\footnotetext{
Srov. tamtéž, s. 258, 312.

Srov. tamtéž, s. 274.

Srov. tamtéž, s. 358.

Tamtéž, s. 359.

Srov. tamtéž, s. 360-363.
} 
potvrzovala naše teze, kterou jsme vyslovili ve studii věnované $M$. D. Leroymu, ${ }^{61}$ totiž že jeho kniha z roku 1891 nevyjadřovala pouze jeho osobní mínění. Třetím zastáncem tohoto mínění byl opat Fabre d'Envieu, který se tímto způsobem vyjádřil ve svém díle Les origines de la terre et de l'honnne, d'aprés la Bible et d'aprés la science, konkrétněji na straně 459. Z našeho badatelského hlediska se jedná o další průkopníky recepce evolučního vzniku - stvoření člověka ze strany katolické teologie. Byt' danou věc na rovině možnosti Z. Gonzáles nevylučuje, považuje však za vědecky nepř́ípustné předkládat tyto hypotézy jako prokázanou skutečnost. ${ }^{62}$ Následně se hovoří o francouzském paleontologovi Gaudrym, který prezentoval svůj nález Dryopitheca. Celkový závěr je evidentní: „Z toho všeho se vyvozuje, že v průběhu třetihorní epochy v Evropě neexistoval ani člověk, ani žádný tvor, který by se mu blížil nebo se mu podobal.“63 Kouzelné je, že dnešní paleontologové by takové hodnocení zřejmě podepsali i dnes, i když možnosti nových a převratných nálezů není možno nikdy vyloučit.

Dále jsme zpravováni o tom, že tři dánští vědci, konkrétně geolog Forchammer, přírodovědec Steenstrup a archeolog Worde, rozlišili dobu kamennou, bronzovou a železnou, s čímž Z. Gonzáles rozhodně neměl pražádné problémy. ${ }^{64}$ Nebránil se ani rozlišování paleolitu a neolitu, v čemž si z jeho díla měli vzít př́íklad jiní teologové, kteří $\mathrm{s}$ danou periodizací zápolili ještě zpočátku 20. století. ${ }^{55}$ Španělskému filosofovi je jasné, že v dějinách lidstva existovaly čtyři základní epochy (paleolit, neolit, doba bronzová a železná), $v$ jeho době ale ještě nebylo možné s jistotou stanovit absolutní dataci. ${ }^{66}$ Taktéž stáří lidstva je mnohem, mnohem vyšší, než se dříve mělo za to, nicméně v roce

${ }^{61} \mathrm{~V}$ době vzniku tohoto článku zmíněná studie ještě nevyšla v periodiku Studia theologica, a proto na ni nemůžeme na tomto místě přímo odkazovat. Podtržení dalšího argumentu ve prospěch námi vyslovené teze, podle níž se mnozí francouzští dominikáni klonili k evolučnímu vzniku - stvoření člověka již na počátku devadesátých let 19. století, vyvolala pochybnost ze strany zasvěceného recenzenta oné studie, a proto další argument v její prospěch zdůrazňujeme poněkud zřetelněji.

${ }^{62}$ Srov. tamtéž, s. 364.

63 „De aquí se deduce que durante el período terciario no existía en Europa, ni el hombre, ni criatura alguna que á él se acercara ó asemejara.“ Tamtéž, s. 368.

64 „... la existencia de una edad de piedra, anterior, distinta y separada de la de los metales, aunque está comprobada con relación á las principales regiones de la Europa.“ („... existence doby kamenné, která předchází dobu kovovou, předchází ji a je od ní odlišná, je prokazatelná v hlavních krajinách Evropy.“) Tamtéž, s. 388.

65 Srov. tamtéž, s. 369-370.

66 Srov. tamtéž, s. 436. 
1891 opět nebylo možno jasně stanovit absolutní dataci. ${ }^{67}$ Kardinál pak předkládá velmi důležité konstatování:

Církev dávala vždy naprostou svobodu mínění v otázkách vztahujících se k biblické chronologii a dodnes nestanovila, že by nějaké datum ohledně stvoření prvního člověka bylo ve shodě nebo v protikladu vzhledem k Bibli. ${ }^{68}$

Čtvrtá kapitola, v níž se Z. Gonzáles kriticky vyrovnává s biblickou potopou, leží mimo pole našeho nynějšího zájmu. Nicméně poctivost př́stupu, rekapitulace velkého počtu různých dobových teorií, kritické vyhodnocování všech údajů i interpretací učiní i na dnešního čtenáře nemalý dojem. Náš autor danou otázku neřeší definitivním způsobem, nicméně je zřejmé, že jeho kriticky myslící rozum se vzpírá přijímat univerzální záplavu celého zemského globu.

\section{Závěr}

Jak již bylo řečeno, nastínění sporů o evolucionismus a darwinismus ve Španělsku v období 1860 až 1910 i prezentace základní rysů životních osudů a díla kardinála Z. Gonzálese představuje nespornou novinku v české jazykové oblasti. Zkoumání jeho posledního rozsáhlého a také velmi významného díla potvrdilo, že tento velmi kriticky myslící katolický filosof i přírodovědec jednak velmi dobře vyhodnocoval věrohodnost tvrzení dobových přírodovědců, jednak neváhal přistupovat k výkladu textů z knihy Genesis věcně a racionálně. Byl otevřený transformismu i určité formě evoluce jak v oblasti fauny a flóry, tak dokonce na rovině vzniku - stvoření člověka. Pochopitelně velmi důrazně podtrhoval, že dané procesy jsou neseny působením Boha jako Stvořitele. Obhajoval nerozpornost Mivartovy teze se zjevením a naukou církve, nicméně danou hypotézu modifikoval, protože tělo připravené vývojem nebylo ještě plně lidským, tím se stalo až v okamžiku sjednocení s racionální duší, čímž se vylučuje riziko latentního dualismu a zároveň se činí zadost tradiční exegezi biblických textů

67 Srov. tamtéž, s. 438.

68 „La Iglesia ha permitido en todo tiempo completa libertad de opinión en las cuestiones referentes á la cronología bíblica, y hasta la hora presente no ha fijado fecha alguna para la creación del primer hombre como conforme ó contraria á la Biblia.“ Tamtéž, s. 514. 
o stvoření člověka. Podivuhodně otevřený byl tento autor vůči př́ínosům rodící se prehistorické archeologie, paleontologie, geologie i astronomie. Význam jeho vynikajícího myšlenkového př́nosu podtrhuje navíc jeho vysoké postavení v církevní hierarchii. Je to jediný kardinál katolické církve, který tak záhy propojil možnost evolučního vzniku lidského těla s údaji zjevení a s učením církve.

Z hlediska toho, co již o celém svízelném procesu probojovávání recepce transformisticky koncipovaného vzniku - stvoření člověka v letech 1871-1910 víme, je vhodné podotknout, že španělští myslitelé znali velmi dobře zahraniční literaturu, nicméně němečtí, francouzští a italští autoři nevěděli nic o oněch španělských. Obdobná schémata přezírání přínosů myslitelů pocházejících z určitých národů bohužel přetrvávají v mnohém až dodnes.

Neopomenutelným výtěžkem našeho snažení je také zjištění dalších tří jmen francouzských průkopníků akceptování evolučního vzniku - stvoření lidského těla ze strany katolických myslitelů již v osmdesátých letech a na počátku devadesátých let 19. století, čímž se opětně potvrzuje naše zjištění, podle něhož $M$. D. Leroy, když editoval v roce 1891 svou knihu o evoluci a vzniku člověka, vyjadřoval nikoli pouze své vlastní mínění, ale také to, co bylo v myslích nejednoho francouzského dominikána a učeného duchovního v oné době.

Katolická teologická fakulta Univerzity Karlovy Thákurova 3 16000 Praha 6 E-mail: cpospisil@volny.cz 